\author{
Radosław Tarkowski \\ ORCID: 0000-0003-3294-1246 \\ Instytut Gospodarki Surowcami Mineralnymi i Energia \\ Polskiej Akademii Nauk (Kraków, Polska) \\ tarkowski@min-pan.krakow.pl
}

\title{
Polscy przyrodnicy: Konstanty Jelski, Jan Sztolcman oraz Jan Kalinowski i ich wkład w badania przyrodnicze Peru w drugiej połowie XIX i na początku XX wieku
}

\begin{abstract}
Abstrakt
Polscy przyrodnicy: Konstanty Jelski (1837-1896), Jan Sztolcman (1854-1928) oraz Jan Kalinowski (1857-1941) działali w Peru w drugiej połowie XIX oraz na początku XX wieku. Jelski przebywal w Peru w latach 1869-1879, Sztolcman dwukrotnie w latach 1875-1881 i 1882-1884, Kalinowski zaś przybył w 1889 roku i pozostał w tym kraju aż do śmierci.

Ich pobyt mial na celu zebranie bogatej, mało znanej fauny, głównie ptaków, a prace tych przyrodników były sponsorowane przez rodzinę Branickich. Zebrane okazy fauny były

\begin{tabular}{|c|c|c|c|c|}
\hline $\begin{array}{l}\text { INFORMACJA } \\
\text { O PUBLIKACJI }\end{array}$ & Pistoriae & $\begin{array}{r}\text { e-ISSN 2543-702X } \\
\text { ISSN 2451-3202 }\end{array}$ & s. & $\begin{array}{l}\text { } \\
\text { BRYLANTOWY MODEL } \\
\text { OTWARTEGO DOSTĘPU }\end{array}$ \\
\hline \multicolumn{5}{|c|}{$\begin{array}{l}\text { CYTOWANIE } \\
\text { Tarkowski, Radosław 2021: Polscy przyrodnicy: Konstanty Jelski, Jan Sztolcman oraz Jan Kalinowski } \\
\text { i ich wkład w badania przyrodnicze Peru w drugiej połowie XIX wieku. Studia Historiae Scientiarum 20, } \\
\text { ss. 569-599. DOI: } 10.4467 / 2543702 X S H S .21 .016 .14047 .\end{array}$} \\
\hline \multicolumn{2}{|c|}{$\begin{array}{l}\text { OTRZYMANO: } 17.03 .2020 \\
\text { ZAAKCEPTOWANO: } 28.06 .2021 \\
\text { OPUBLIKOWANO ONLINE: } 13.09 .2021\end{array}$} & $\begin{array}{l}\text { POLITYKA } \\
\text { ARCHIWIZOWANIA } \\
\text { Green SHERPA / } \\
\text { RoMEO Colour }\end{array}$ & $\begin{array}{l}\text { LICENCJA } \\
\text { (c) (i) }\end{array}$ & 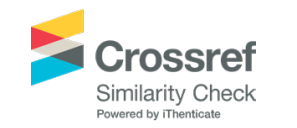 \\
\hline
\end{tabular}
\end{abstract}


przesyłane do Warszawskiego Gabinetu Zoologicznego zarządzanego przez W. Taczanowskiego oraz do prywatnego muzeum Branickich przy Frascati. Materiały zebrane przez polskich przyrodników wzbogaciły zbiory wielu instytucji naukowych w Polsce, również tych zagranicznych. Okazy fauny były podstawą do opisu wielu nowych gatunków nieznanych nauce.

Nazwiska polskich przyrodników są znane do dziś specjalistom od fauny i flory neotropikalnej. Pojawiają się często w nazwach nowych gatunków opisanych na podstawie odkrytych przez nich okazów.

Przesłane z Peru zbiory uczyniły Warszawski Gabinet Zoologiczny ośrodkiem badań neotropikalnej awifauny na światowym poziomie, a kolekcja ta była konsultowana przez specjalistów z całej Europy. Ptaki z Peru stanowiły podstawę opracowania monografii Ornithologie du Pérou W. Taczanowskiego.

Kolekcje oraz obserwacje Jelskiego i Sztolcmana wniosły znaczący wkład w przygotowanie dzieła A. Raimondiego El Peru. Sztolcman opublikowal dwutomowe dzieło Peru. Wspomnienia zpodróży z. mapq stanowiące ważny wkład Polski w poznawanie tego kraju. Ptaki i ssaki zebrane przez Kalinowskiego w Peru wzbogaciły kolekcje muzeów w Limie, Waszyngtonie, Londynie, Warszawie.

Słowa kluczowe: Konstanty Jelski, Jan Sztolcman, Jan Kalinowski, Wtadystaw Taczanowski, Antonio Raimondi, Peru, Ameryka Poludniowa, mecenat Branickich, badania prsyrodnicze, XIX wiek, poczatek XX wieku

\title{
Polish naturalists: Konstanty Jelski, Jan Sztolcman and Jan Kalinowski and their contribution in Peru's nature research in the second half of the $19^{\text {th }}$ and the earliest of the $20^{\text {th }}$ century
}

\begin{abstract}
Polish naturalists: Konstanty Jelski (1837-1896), Jan Sztolcman (1854-1928) and Jan Kalinowski (1857-1941) were active in Peru in the second half of the $19^{\text {th }}$ and earliest of $20^{\text {th }}$ century. Jelski stayed in Peru in the years 1869-1879, Sztolcman twice in the
\end{abstract}


years 1875-1881 and 1882-1884, and Kalinowski arrived in 1889 and stayed in Peru until his death.

Their stay was aimed at collecting rich, little-known fauna, mainly birds. The work of these naturalists was sponsored by the Branicki family. The collected fauna specimens were sent to the Zoological Cabinet in Warsaw managed by W. Taczanowski and to the private Branicki Museum (the Frascati Palace). The materials collected by the Polish naturalists have enriched the collections of many scientific institutions in Poland, including foreign ones. The fauna specimens were the basis for the description of many new species unknown to science.

The names of Polish naturalists are known to specialists in neotropical fauna and flora to this day. They often appear in the names of new species described on the basis of the specimens they discovered.

The collections sent from Peru made the Zoological Cabinet in Warsaw a center of research on neotropical avifauna at the world level, and the collection was consulted by specialists from all over Europe. The birds from Peru were the basis for W. Taczanowski's monograph Ornithologie du Pérou.

The collections and observations of Jelski and Sztolcman made a significant contribution to the preparation of the work ElPeru by A. Raimondi. Sztolcman published a two-volume work: Peru. Wspomnienia z podrózy z mapa an important contribution of Poland to the knowledge of Peru. The birds and mammals collected by Kalinowski in Peru enriched the collections of museums in Lima, Washington, London and Warsaw.

Keywords: Konstanty Jelski, Jan Sztolcman, Jan Kalinowski, W Wadysław Taczanowski, Antonio Raimondi, Peru, South America, patronage of the Branicki family, natural science research, $19^{\text {th }}$ century, earliest $20^{\text {th }}$ century.

\section{Wprowadzenie}

Ameryka Południowa ze względu na bogactwo roślin, zwierząt, minerałów, a także pozostałości dawnych kultur stanowiła od XVIII wieku przedmiot zainteresowania przyrodników. Początkowo ich wyprawy były finansowane przez dwory europejskie współzawodniczące we wspieraniu ekspedycji organizowanych przez zespoły naukowców, podróżujących po oceanach i kontynentach, aby rozwijać wiedzę geograficzna, astronomiczną, zoologiczną, botaniczną i mineralogiczna. 
Widziały w tym możliwość poznania i lepszego wykorzystania bogactw naturalnych rozproszonych po świecie, co miało istotne znaczenie dla rozwoju handlu. Od początku XIX wieku podróże te były również związane $z$ rozwojem przemysłu i zwiększonym zapotrzebowaniem na surowce mineralne $e^{1}$.

Uczestnikami wypraw, które przybyły do Ameryki Południowej z Hiszpanii w pierwszej połowie XVIII wieku, był żeglarz i matematyk Jorge Juan (1713-1773) oraz przyrodnik i generał Antonio de Ulloa (1716-1795). W drugiej połowie XVIII wieku byli to: hiszpański odkrywca i żeglarz Alejandro Malespina (1754-1810); urodzony w Czechach Tadeo Haenke (1761-1817); pochodzacy z Lotwy baron Timoteus von Nordenflycht (1752-1815) oraz inni. Wyprawy podróżnicze w tamtych czasach trwały po kilka lat, składały się z zespołów specjalistów z różnych dziedzin nauki oraz odmiennych narodowości. Ich wynikiem były kolekcje okazów oraz zapiski w księgach z podróży rejestrujące obserwacje dokonane przez przyrodników i eksploratorów. Przywiezione materiały, po powrocie do Europy, były przedmiotem dalszych badań i opracowań.

Wiek XIX to okres kolejnego wielkiego rozkwitu wypraw naukowych - nastąpił wielki postęp w badaniach egzotycznej fauny i flory. Często określany jako złoty wiek kolekcji przyrodniczych ${ }^{2}$. Zainteresowanie to wynika z epoki kolonialnej i znaczenia przypisywanego zasobom naturalnym tropików. Nastąpił znaczący postęp badań naukowych i kompetencji władz w zakresie wiedzy, która pozwoliłaby im wykorzystać bogactwa naturalne innych obszarów. Wyprawy planowane przez rządy otworzyły drogę do odkryć naukowcom zatrudnionym przy uniwersytetach, muzeach i innych ośrodkach badawczych. Był to również okres organizowania kolekcji i muzeów historii naturalnej opartych na obiektach sprowadzonych z kolonii. Pragnienie przygód inspirowane romantyzmem dodatkowo zachęcało młodych ludzi do poszukiwania przeżyć i przygód w egzotycznych krajach.

Przyroda Ameryki Południowej była w XIX wieku uważana za raj dla przyrodników ${ }^{3}$. Obraz ten wynikał z jej bogactwa pod względem fauny i flory, również relacji z podróży poczynionych przez Alexandra

1 Daszkiewicz 2005, s. 75.

${ }^{2}$ Daszkiewicz 1997, ss. 9, 14.

3 Daszkiewicz 2005, s. 77. 
von Humboldta (1769-1859), podróżującego po Ameryce Południowej w towarzystwie francuskiego botanika Aimé Bonplanda (1773-1858), angielskiego przyrodnika Karola Darwina (1809-1882), paleontologa francuskiego Alcida Orbigny'ego (1802-1857), francuskiego przyrodnika i podróżnika Francisa Castelnau (1812-1880), szwajcarskiego przyrodnika barona Johanna Jacoba von Tschudi (1818-1889), podróżnika i zbieracza roślin Józefa Warszewicza (1812-1866) oraz innych4 .

W drugiej połowie XIX wieku zmieniła się metodyka prowadzenia badań naukowych. Umocnił się podział ról między przyrodnikami pracującymi w gabinetach naukowych a przyrodnikami odkrywcami. Pierwszy opisywał nowy gatunek, pracując nad materiałem przesłanym przez swoich współpracowników, zwykle odkrywców, a także nad okazami zgromadzonymi w różnych kolekcjach. Natomiast przyrodnicy w terenie polowali, zbierali i preparowali okazy przeznaczone do zbiorów ${ }^{5}$. Podział ten uwidocznił się również w działalności polskich przyrodników działających w Peru oraz ich patronów w Warszawie.

Peru ze względu na uwarunkowania przyrodnicze oraz bogactwo fauny i flory neotropikalnej stanowiło od dawna przedmiot zainteresowań zoologów i botaników. W trzecim co do wielkości państwie Ameryki Południowej, przyrodnicy prowadzili swoje prace w trzech krainach geograficznych (idąc z zachodu na wschód): Costa (wybrzeże), Sierra (góry) i Montania, czyli Selva (Amazonia peruwiańska, rozległe zalesione podnóża gór oraz równiny). Costa to długi, wąski pas pustynnych nizin na wybrzeżu Oceanu Spokojnego; leży tu większość miast peruwiańskich. Sierra to peruwiańska część Andów o szerokości od 95 $\mathrm{km}$ na północy do $320 \mathrm{~km}$ na południu Peru, składająca się z pasma Kordylierów Zachodnich, Środkowych oraz Wschodnich, o średniej wysokości 2750-5800 m n.p.m. Montania to wilgotny obszar o wysokości 80-1000 m n.p.m. obejmujący wschodnie podnóża Andów, który porastają wilgotne lasy równikowe Niziny Amazonki. Średnia roczna temperatura waha się między $19-22^{\circ} \mathrm{C}$ na wybrzeżu, $1-14^{\circ} \mathrm{C}$ w Andach, $24-35^{\circ} \mathrm{C}$ w lasach wschodnich. Suma opadów jest najwyższa na wschodzie (od $1900-3175 \mathrm{~mm}$ ) i bardzo niska (ok. $50 \mathrm{~mm}$ ) na suchym wybrzeżu. Linia wiecznego śniegu przebiega na wysokości 4480 do

${ }^{4}$ Więcej: Piechnik, Kurek 2016, ss. 35-76.

${ }^{5}$ Daszkiewicz 1997, ss. 13-15; 2005, s. 80. 
5000 m n.p.m. Zachodnią krainę nadbrzeżna porasta skąpa roślinność, w górach występują natomiast wiecznie zielone krzewy, kaktusy, zielone trawy. Montania to region pokryty gęstą roślinnością, głównie rozległymi lasami deszczowymi ${ }^{6}$. W takich warunkach geograficznych przyszło działać polskim przyrodnikom? ${ }^{7}$.

Działalność polskich przyrodników - Konstantego Jelskiego, Jana Sztolcmana oraz Jana Kalinowskiego w Peru w drugiej połowie XIX oraz na początku XX wieku była dotychczas przedmiotem kilku odrębnych publikacji. O ile poczynania K. Jelskiego w Peru są najlepiej poznane dzięki monograficznemu opracowaniu autora ${ }^{8}$, informacje o pobycie J. Sztolcmana w Peru pochodza głównie z jego wspomnień ${ }^{9}$ oraz opracowania autora we współpracy z T.W. Pyrczem oraz Katarzyną Gołuchowską T. Dunin-Borkowski ${ }^{10}$. Natomiast opracowanie Kalinowski Julio Sumar ${ }^{11}$ wnosi wiele nowych informacji o życiu J. Kalinowskiego w Peru, w kraju, w którym spędził on większość swego życia ${ }^{12}$.

W prezentowanym artykule autor postanowił przedstawić działalność polskich przyrodników działających w Peru w drugiej połowie XIX wieku i na początku XX wieku - K. Jelskiego, J. Sztolcmana i J. Kalinowskiego - ich wkład w poznanie fauny i flory Ameryki Południowej. Zostało to przybliżone na tle badań przyrodniczych w Ameryce Południowej w XIX wieku, uwarunkowań geograficznych, w których przyszło działać polskim przyrodnikom w tym kraju, współpracy z W. Taczanowskim oraz Antonio Raimondim. Wykorzystane informacje zostały zaczerpnięte $z$ wcześniejszych publikacji autora dotyczących

${ }^{6}$ Peru. W: Encyclopedia Britannica, ss. 408-411; więcej: Piechnik, Kurek 2016.

7 Więcej: Tarkowski, Goluchowska Trampczynska 2016.

8 Tarkowski 2011.

9 Sztolcman 1912.

10 Tarkowski i in. 2017.

11 J.S. Kalinowski 2017.

12 Z polskich przyrodników działających w Peru w pierwszej połowie XX w. należy również wspomnieć o Feliksie Woytkowskim (1892-1966), entomologu, floryście, kolekcjonerze przyrodniczym, który w 1928 r. z grupą Polaków wyemigrował do Peru i do 1934 r. był kolonista. W 1934 r. osiedlił się w Limie i rozpoczął pracę kolekcjonerską. Współpracował m.in. z instytucjami przyrodniczymi w USA, Wielkiej Brytanii, Peru i w innych krajach. Zbierał w Peru rośliny lecznicze dla firmy CIBA w Szwajcarii. Odbył ok. 60 wypraw w górzyste tereny Peru, dostarczył liczne okazy roślin i zwierząt dla instytucji naukowych Europy i obu Ameryk. Autor książki Peru - moja ziemia nieobiecana (więcej: Wielopolska 1974; Woytkowski 1987). 
Konstantego Jelskiego oraz Jana Sztolcmana ${ }^{13}$. W przypadku Jana Kalinowskiego, uzupełniono je o informacje z publikacji cytowanych w tekście artykułu ${ }^{14}$.

\section{Władysław Taczanowski i rola warszawskiego Gabinetu Zoologicznego w badaniach fauny neotropikalnej}

Władysław Taczanowski (1819-1890), znany głównie z badań i publikacji ptaków Ameryki Południowej oraz Syberii, przez długie lata pełnił funkcję kustosza warszawskiego Gabinetu Zoologicznego ${ }^{15}$. Dzięki jego niesłychanemu talentowi organizacyjnemu i wysokim kwalifikacjom zawodowym instytucja ta zmieniła się z małej prowincjonalnej kolekcji w jeden z najbardziej dynamicznych ośrodków badań fauny neotropikalnej w Europie, na zbiorach którego pracowało wielu wybitnych przyrodników z kilkunastu krajów. Nawiązana w 1864 roku ścisła współpraca z Konstantym i Aleksandrem Branickimi zapewniła Gabinetowi stały mecenat ${ }^{16}$.

Podstawa badań Taczanowskiego nad ornitofauną Peru, Gujany Francuskiej, Ekwadoru, Boliwii były zbiory, które nadsyłali do

13 Najważniejsze z nich: Tarkowski 2011; 2012; 2016; Tarkowski i in. 2017; Daszkiewicz, Trakowski 2007b; 2007c.

${ }^{14}$ Najważniejsze z nich: J.S. Kalinowski 2017; Paradowska 1977; Piechnik, Kurek 2016.

15 Gabinet Zoologiczny powstał w 1819 roku przy Królewskim Uniwersytecie Warszawskim jako placówka edukacyjna i naukowa. Jej długoletnim kustoszem (18621890) był W. Taczanowski. Więcej: Piechnik, Kurek 2016, ss. 80-85.

${ }^{16}$ Konstanty Branicki, a po jego śmierci Aleksander Branicki, pokrywali koszty ekspedycji i eksploracji przyrodniczych polskich przyrodników prowadzone w Ameryce Południowej, na Syberii oraz w Afryce. Około 1880 r., dzięki inicjatywie (również W. Taczanowskiego) i funduszom rodziny, z obawy, aby władze rosyjskie nie wywiozły zbiorów do Rosji, Ksawery Branicki (1864-1926) zainicjował działalność Muzeum hr. Branickich w pałacyku Frascati, działające od 1887 roku jako prywatne muzeum zoologiczne. Od tego czasu wszystkie cenniejsze materiały, nadsyłane z całego świata przez polskich przyrodników, przekazywane były do kolekcji Branickich. W roku 1919 Braniccy ofiarowali swe zbiory społeczeństwu, a z połączenia Muzeum Branickich i Gabinetu Zoologicznego powstało Polskie Państwowe Muzeum Przyrodnicze, przemianowane w roku 1928 na Państwowe Muzeum Zoologiczne (Muzeum i Instytut Zoologii Polskiej Akademii Nauk 2020). Więcej: Taczanowski 1964. 


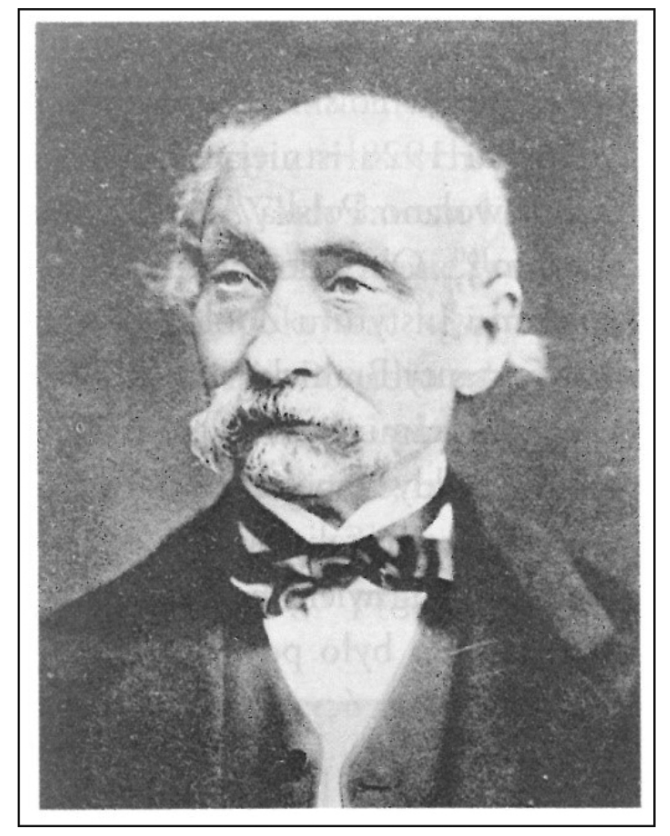

Ryc. 1. Władysław Taczanowski (C) Muzeum i Instytut Zoologii PAN w Warszawie)

warszawskiego gabinetu, finansowani przez rodzinę Branickich, polscy podróżnicy i odkrywcy: Konstanty Jelski (z Gujany Francuskiej i Peru) i Jan Sztolcman (z Peru i Ekwadoru), w mniejszym stopniu Jan Kalinowski (z Peru i Boliwii). Dzięki współpracy z tymi przyrodnikami oraz Antonio Raimondim (1826-1890), Taczanowski przygotował wydaną we Francji, 4-tomową Ornithologie du Pérou (1884-1886), pierwszą i najobszerniejszą w XIX wieku monografię zoologiczną fauny neotropikalnej ${ }^{17}$. Taczanowski, chociaż brał udział jako kolekcjoner w róż-

17 Czterotomowe opracowanie Taczanowskiego Ornithologie du Pérou (1884-1886), której pierwszy tom został wydrukowany w Rennes w 1884 roku, to jedno z najważniejszych dzieł przyrodniczych XIX wieku, najbardziej kompletna do dziś monografia ornitofauny Peru. Ze względu na systematyczną eksplorację dużych części kraju przez wysoko wykwalifikowanych przyrodników, badanie okazów we wszystkich znanych kolekcjach, pracę w sieci specjalistów z kilku krajów, jest ona uznawana za owoc prawdziwego programu badań naukowych. (Więcej: Daszkiewicz 2005; Vuilleumier 2003). Opisano w niej 1349 gatunków peruwiańskich ptaków, z których 198 po raz pierwszy (w tym 60 na podstawie okazów wysłanych do Warszawy przez Jelskiego i Sztolcmana), 
nych wyprawach, nigdy nie odwiedził Ameryki Południowej, korzystał natomiast $\mathrm{z}$ okazów przesłanych $\mathrm{z}$ tego kontynentu przez Jelskiego i Sztolcmana oraz wymianie okazów z A. Raimondim, również i tych znajdujących się w europejskich kolekcjach ${ }^{18}$.

Przygotowując Ornithologie du Pérou Taczanowski uwzględnił również inne publikacje i spostrzeżenia, a zwłaszcza informacje uzyskane dzięki francuskim wyprawom A. d'Orbigny'ego i F. Castelnau, także brytyjskim podróżnikom po Ameryce Północnej i Południowej, opublikowane w Londynie przez angielskiego ornitologa P.L. Sclatera (1829-1913) oraz przyrodnika i ornitologa O. Salvina (1835-1898) przedstawione w licznych publikacjach. Dzięki Sztolcmanowi zbadał również niektóre pomniejsze kolekcje zgromadzone w Peru.

\section{Antonio Raimondi i jego rola w przyrodniczym poznaniu Peru}

Antonio Raimondi (1824-1890) - geograf, chemik i botanik, geolog, członek najważniejszych towarzystw naukowych na świecie, należy do czołowych XIX-wiecznych uczonych związanych z Ameryką Południowa. Z rodzinnych Włoch w $1850 \mathrm{r}$. przybył do Peru, gdzie spędził resztę życia ${ }^{19}$. W latach 1851-1869 podróżował niestrudzenie przez ten kraj. Gromadził i inwentaryzował materiały, tworzył kolekcje roślin, minerałów, skamieniałości i zwierząt z wybrzeża, gór i peruwiańskiej dżungli, prowadził obserwacje barometryczne, meteorologiczne, a mając zdolności do rysowania robił szkice regionów, które badał ${ }^{20}$. W 1869 roku zakończył podróże po kraju i postanowił opublikować wszystko, co zgromadził, a kolekcje zebrane w ciagu dziewiętnastu lat przekazał

wśród których około 800 było własnością kolekcji warszawskiej. Liczba gatunków opisanych w Ornithologie du Pérou Taczanowskiego jest około czterokrotnie większa niż w opracowaniu Tschudi'ego.

18 Daszkiewicz 2005, ss. 81-83.

19 A. Raimondi we Włoszech podjął działania na rzecz walki o niepodległość i jedność Włoch, a w następstwie jego niepowodzenia był zmuszony do emigracji i wyjechał do Peru. Cayetano Heredia, reformator nauczania medycyny w Peru, zlecił mu sklasyfikowanie gabinetu fizyki i historii naturalnej Colegio de la Independencia (późniejszy Wydział Lekarski) w Limie. W 1862 r. Raimondi uzyskał doktorat z nauk przyrodniczych na Uniwersytecie San Marcos. (Więcej: Broggi 1926; Villacorta 2010).

${ }^{20}$ Museo Raimond Asociación Educacional Antonio Raimondi 2020. 
państwu peruwiańskiemu ${ }^{21}$. Niestety, wojna z Chile przerwała publikację wyników Raimondiego ${ }^{22}$.

Celem badań Raimondiego był jak najdokładniejszy opis przyrody, w szczególności bogactw naturalnych tego kraju, który przed przyjazdem Raimondiego pozostawał praktycznie nieznanym. Owocem jego 40-letnich badań, obejmujących setki zorganizowanych wypraw i wycieczek, jest wielotomowe dzieło El Peru (Raimondi, 1874-1913), pierwszy nowoczesny opis geograficzny i geologiczny tego kraju, nadal najpełniejszy opis przyrody tego regionu ${ }^{23}$. Monograficzne opracowanie Raimondiego stanowiło przełom dla historii nauki w Ameryce Południowej. W porównaniu do wcześniejszych rezultatów badań w pierwszej połowie XIX wieku, takich przyrodników jak: A. Humboldt, K. Darwin, T. Haenke, M.F. Paza Soldána oraz innych, Raimondi osiadł w Ameryce Południowej na wiele lat, zorganizował w Peru sieć współpracowników oraz instytucji naukowych ${ }^{24}$. Po raz pierwszy w historii kontynent ten nie był badany przez podróżników, misjonarzy czy urzędników kolonialnych, lecz przez profesjonalnych naukowców i inżynierów, którzy byli w służbie rządu peruwiańskiego ${ }^{25}$.

\section{Polscy inżynierowie i przyrodnicy w otoczeniu Antonio Raimondiego}

Ameryka Południowa to kontynent, na którym w XIX w. działała liczna grupa Polaków. Odznaczyli się w wielu dziedzinach życia gospodarczego oraz społeczno-politycznego i kulturowego, pracowali tu m.in.

${ }^{21}$ W 1869 roku Raimondi ożenił się z Huaraciną Adelą Loli, z którą miał troje dzieci. Zmusiło go to do zmiany trybu życia i podjęcia starań znalezienia odpowiedniej osoby, którzy zastapiliby go w badaniach terenowych. Tą osobą okazał się K. Jelski (Tarkowski 2011, ss. 117-126).

${ }^{22}$ Raimondi miał propozycję wyjazdu z Peru, razem ze swoimi zbiorami, czemu odmówił (Asociación Educacional Antonio Raimondi 2020).

${ }^{23}$ Jego liczne inne publikacje dotyczyły m.in. badań guano, saletry, roślin leczniczych, wód pitnych i termalnych, bogactw mineralnych.

${ }^{24}$ Ze względu na prestiż, Raimondi był konsultantem największych przedsięwzięć prowadzonych w Peru, takich jak: lokalizacja drogi do budowy linii kolejowej, lokalizacja złóż mineralnych dla budowy kopalń, certyfikacja próbek minerałów, kryteria rozgraniczenia terytorialnego, doradztwo w sprawie konfliktów z sąsiednimi krajami oraz inne.

25 Więcej: Daszkiewicz, Tarkowski 2007a; 2007b; Tarkowski 2016. 


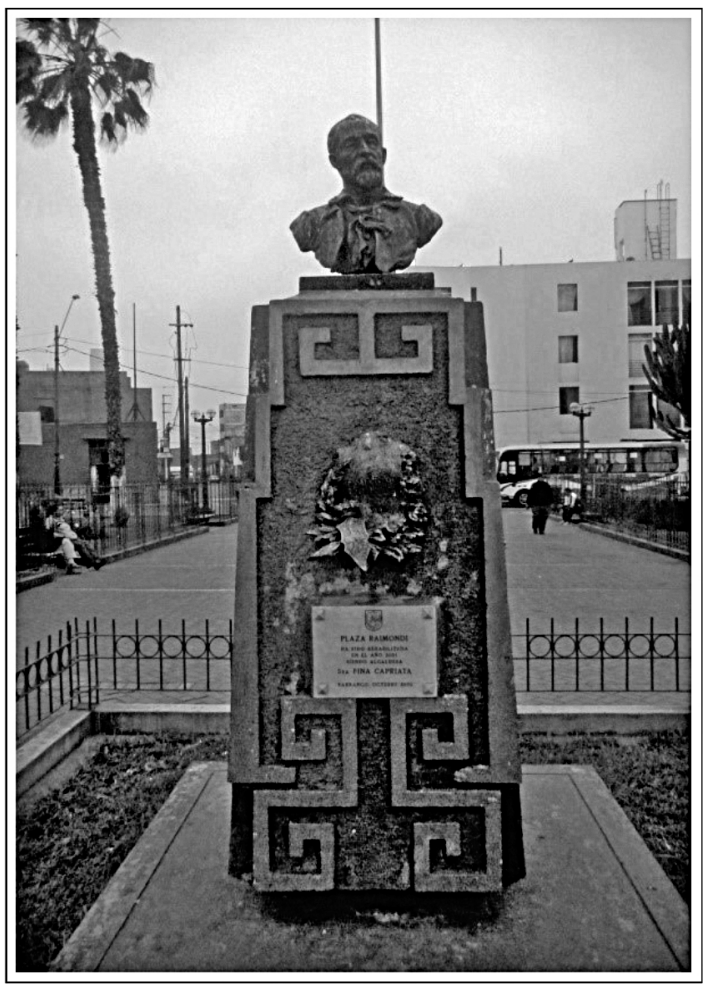

Ryc. 2. Pomnik A. Raimondiego w Limie w dzielnicy Barranco na placu jego imienia (zdjęcie własne autora).

jako inżynierowie, przyrodnicy, geolodzy, technicy, architekci, lekarze, nauczyciele. Po upadku powstania listopadowego do Ameryki Południowej przybyli: Ignacy Domeyko ${ }^{26}$, Ernest Malinowski ${ }^{27}$, Józef War-

${ }^{26}$ Ignacy Domeyko (1802-1889) - geolog, mineralog, inżynier górnictwa, wieloletni rektor Universidad de Chile. Raimondi przesyłał Domeyce nie tylko publikacje, ale i okazy, a nawet kolekcje mineralogiczne i geologiczne (Więcej: Daszkiewicz, Tarkowski 2007b; 2007c; 2020; Ryn 2002).

${ }^{27}$ Ernest Malinowski (1818-1889) przybył do Peru w 1852 r. i pozostał w tym kraju aż do śmierci. Był świadkiem na ślubie Raimondiego, bliskim przyjacielem rodziny, jednym z inicjatorów a zarazem członkiem rządowej komisji zabezpieczającej i badającej spuściznę Raimondiego, zaprojektował najwyżej położoną na świecie linię kolejowa - Centralną Kolej Transandyjska, przyczynił się do obrony portu Callao, był kierownikiem katedry topografii w Limie. (Więcej: Daszkiewicz, Tarkowski 2007a; 2007b; Tarkowski 2016; Paradowska 1977; W. Słabczyński, T. Słabczyński 1992). 
szewicz ${ }^{28}$. Fiasko powstania styczniowego przyczyniło się do dalszej emigracji Polaków. Uciekając przed prześladowaniami politycznymi, bądź też z powodu braku perspektyw zawodowych w Europie, czy też w poszukiwaniu lepszej egzystencji, opuszczali oni kraj ojczysty. Część emigrantów znalazła drugą ojczyznę w Ameryce Południowej, również w Peru. Wielu z nich odniosło sukcesy, a ich nazwiska są wspominane do dzisiaj. Istnienie dużej polskiej diaspory było kolejnym czynnikiem wyboru Peru jako miejsca wyjazdu z Europy ${ }^{29}$.

W drugiej połowie XIX wieku wielu Polaków mieszkało i pracowało w Limie. Polscy inżynierowie i technicy oraz przyrodnicy odegrali szczególnie ważną rolę w polityce rozwoju gospodarczego Republiki Peru. Wśród współpracowników Raimondiego stanowili oni jedną z najliczniejszych grup ${ }^{30}$. Uchodźcy polityczni z okupowanej przez zaborców Polski, często wysoko wykwalifikowani inżynierowie i naukowcy, najpierw trafiali do Francji. Tutaj pozbawieni perspektyw znalezienia zatrudnienia odpowiadającego ich kwalifikacjom, decydowali się na dalszą podróż za ocean. Władze peruwiańskie rozumiały konieczność przyrodniczego zbadania kraju oraz celowość sprowadzenia wysoko wykwalifikowanej kadry naukowo-technicznej ${ }^{31}$.

Antonio Raimondi był bliski Polakom mieszkającym w Limie ze względu na swoje zawodowe zainteresowania, przynależność do kręgu inteligencji w Limie, więzy przyjaźni, ale także sympatie polityczne, ponieważ wcześniej angażował się w walkę o niepodległość i zjednoczenie z Włoch. Nic więc dziwnego, że szukał współpracowników w kręgu polskich emigrantów ${ }^{32}$. Ciagle niewiele wiadomo o powiązaniach Raimondiego z naszymi rodakami, a szczególnie na temat udziału Polaków

${ }^{28}$ Józef Warszewicz (1812-1866) podróżnik, zbieracz roślin w Ameryce Południowej i Środkowej. W trakcie drugiej podróży do Ameryki Środkowej i Południowej (1850-1853) przebywał m.in. w Peru i Boliwii, skąd przesłał do Europy tysiące okazów roślin, żywych lub częściej nasion, bulw, kłączy, zasuszonych egzemplarzy do zielników. Przy okazji gromadził również zbiory ornitologiczne, herpatologiczne i malakologiczne. Po powrocie do kraju pracował na stanowisku głównego ogrodnika w Ogrodzie Botanicznym UJ w Krakowie (Warszewicz Józef 1987, ss. 565-566; Warszewicz Józef 2015, ss. 353-355).

${ }^{29}$ Tarkowski 2011, ss. 87-90; Tarkowski, Goluchowska 2013, s. 17.

30 Daszkiewicz, Tarkowski 2007a, s. 121.

31 Więcej: Daszkiewicz, Tarkowski 2007b; Deustua 1986.

32 Daszkiewicz 2005, ss. 78-79. 
w opisie fauny i flory, w sporządzeniu map, rozpoznaniu geologii i geografii tego kraju3.

Wśród przebywających w Peru Polaków kilku było przyjaciólmi Raimondiego i jego współpracownikami naukowymi, inni zaś byli z nim w kontaktach z racji zajmowanej pozycji i wykonywanej pra$\mathrm{cy}^{34}$. Byli to wspomniany już Ernest Malinowski - projektant trasy kolei transandyjskiej, Edward Habich (1835-1909) - rektor politechniki w Limie, inżynier Aleksander Miecznikowski (1836-1873), inżynier górnictwa Aleksander Babiński (1823-1899), inżynier, matematyk, astronom Władysław Folkierski (1842-1904), architekt Tadeusz Stryjeński (1849-1943), inżynier Xawery Wakulski (1843-1925), inżynier w służbie rządowej Peru - Władysław Kluger (1849-1884).

Współpracownikami Raimondiego w Peru byli także polscy przyrodnicy przebywający w Peru: Konstanty Jelski, Jan Sztolcman, Jan Kalinowski oraz Władysław Taczanowski w Warszawie ${ }^{35}$.

\section{Konstanty Jelski (1837-1896)}

Urodzony w 1837 roku w okolicach Mińska, przyrodnik i podróżnik Konstanty Roman Jelski położył duże zasługi w zebraniu kolekcji zoologicznych i botanicznych w Gujanie Francuskiej oraz Peru ${ }^{36}$.

Ukończył gimnazjum w Mińsku. W latach 1853-1856 studiował medycynę w Moskwie, a w 1856-1860 nauki przyrodnicze na Uniwersytecie

33 Tarkowski 2011, ss. 178-184.

34 Więcej: Bratkowski 1975; Daszkiewicz, Tarkowski 2007a; 2007b; Rudowska 1975; W. Słabczyński, T. Słabczyński 1992; Lopez Soria 1999a; 1999b; Orłowski 1984; 1992; Paradowska 1977; 1984.

${ }^{35}$ Należy podkreślić, że zarówno Jelski, jak i Sztolcman przebywali czasowo w Peru, Kalinowski nigdy z Peru do kraju nie powrócił, a W. Taczanowski nigdy w tym kraju nie był.

$\mathrm{Na}$ znaczenie ich związków zwracano uwagę kilkakrotnie. Więcej: Daszkiewicz 2005; Daszkiewicz, Tarkowski 2007a; Mlikovsky 2009; Seiner Lizarraga 2003; Tarkowski 2011; Villacorta 2003; 2010; Wąsowska, Winiszewska-Ślipińska 1996.

${ }^{36}$ K. Jelski był synem Konstantego Michała (1789-1850) i Klotyldy (1801-1872) z Moniuszków, córki Stanisława i Ewy Wojniłłowiczów, miał 8 rodzeństwa. Ożeniony z Heleną Korsakówną (16 października 1883 roku) miał z nią 4 dzieci, z których dwoje zmarło we wczesnym wieku. Więcej: Tarkowski 2011; 2012; Tarkowski, Goluchowska 2013. 


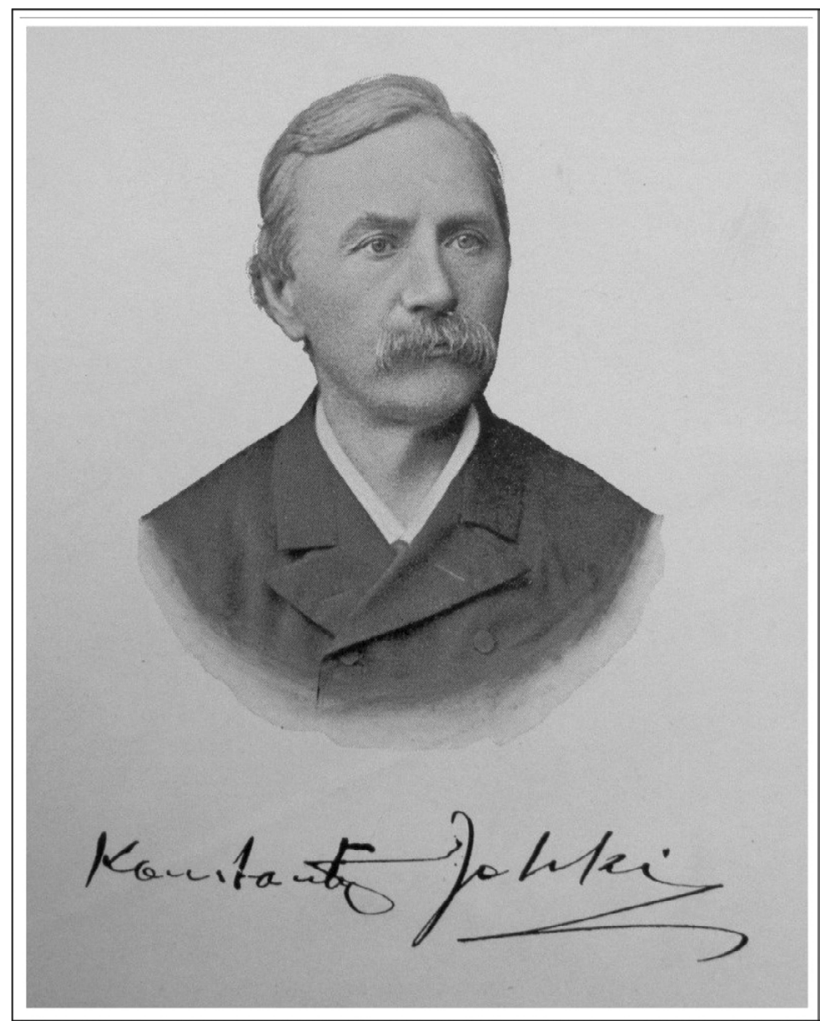

Ryc. 3. Portret K. Jelskiego z pracy pt.: Popularno-pryyrodnicze opowiadania z.pobytu w Gujanie Francuskiej i po çésci w Peru (od roku 1865-1871). Zdjęcie pochodzi z ok. 1875 roku

św. Włodzimierza w Kijowie ${ }^{37}$, gdzie w 1860 r. otrzymał stopnień kandydata. W latach 1860-1862 odbył studia magisterskie w Kijowie, a w październiku 1862 r. uzyskał stopień magistra nauk przyrodniczych ${ }^{38}$. Od października 1862 roku do wyjazdu z Kijowa zarządzal jako kustosz gabinetem zoologicznym uniwersytetu kijowskiego. W maju 1863 r. opuścił Kijów i udał się na teren Imperium Osmańskiego, skąd w czerwcu 1864 r. przybył w poszukiwaniu pracy do Paryża.

Z Francji Jelski wyjechał do Ameryki Południowej, gdzie od września 1864 r. przebywał w Gujanie Francuskiej (1864-1869), a od grudnia 1869 r. w Peru (1869-1879). W Gujanie Francuskiej pracował

37 Studia odbywał pod opieka prof. K. Keslera (Tarkowski 2011, ss. 37-45).

${ }^{38}$ Na podstawie rozprawy pt.: Anatomiczeskoje isledowanie „Lithoglyphus naticoides Fér”. 
w Kajennie w charakterze pomocnika aptekarza, prowadził wykłady z botaniki i rolnictwa w tamtejszym kolegium (1865-1867). W tym okresie dwukrotnie przebywal na rocznych pobytach na wyspach Iles du Salut oraz w Saint Laurent du Maroni. Zbierał okazy przyrodnicze dla Gabinetu Zoologicznego w Warszawie. Od 1868 r. działalność ta była finansowana przez Konstantego Branickiego.

W listopadzie 1869 r. opuścił Gujanę Francuską, by na początku grudnia 1869 r. przybyć do Limy ${ }^{39}$. W Peru prowadził eksplorację fauny i flory oraz badania geologiczne w okolicach Huanty, Tarmy, Guadalupe, Paucal, Cascas, poczattowo dla potrzeb Gabinetu Zoologicznego w Warszawie, wspomagany finansowo przez Konstantego Branickiego. Od 1873 r. stał się oficjalnym współpracownikiem Raimondiego, zatrudnionym do zbierania materiałów związanych z opracowaniem geografii Peru. Po przyjeździe J. Sztolcmana do Limy w październiku 1875 r., do czerwca 1879 r. wspólnie eksplorowali faunę i florę w okolicach Chimbote, Tumbes, Cutervo. Z końcem 1879 r. Jelski wyjechał z Peru, by wiosną 1880 r. przybyć do Krakowa. Od lipca 1880 r. zatrudniony był jako kustosz Komisji Fizjograficznej AU w Krakowie ${ }^{40}$. Zmarł 26 listopada 1896 roku w Krakowie.

Największym osiągnięciem naukowym Jelskiego było dostarczenie setek okazów zwierząt oraz roślin dla zbiorów instytucjonalnych (Gabinet Zoologiczny w Warszawie, Muzeum Komisji Fizjograficznej w Krakowie, muzeum kierowane przez Raimondiego w Limie, Muzeum Zoologiczne w Berlinie, British Museum w Londynie, Imperial Museum w Wiedniu, Muzeum Zoologiczne Akademii Nauk w Petersburgu, Muzeum Historii Naturalnej Smithsonian Institution i inne), dla europejskich przyrodników i kolekcjonerów, właścicieli sklepów zajmujących się sprzedażą i wymianą okazów przyrodniczych (Maison Verreaux i Deyrolle w Paryżu i in.).

Liczni specjaliści polscy i zagraniczni opracowywali okazy zebrane przez Jelskiego w Gujanie Francuskiej i Peru ${ }^{41}$. Mięczaki zostały opisa-

39 To właśnie dzięki staraniom i zachęcie E. Habicha Jelski pozostał w Limie (Tarkowski 2011, ss. 43-44).

40 W latach 1880-1892 z przerwami prowadził wykłady zoologii w Wyższym Zakładzie Naukowym dla Kobiet imienia Dra A. Baranieckiego przy Muzeum Techniczno-Przemysłowym w Krakowie (Tarkowski 2011, ss. 148-149).

${ }^{41}$ Tarkowski 2011, ss. 197-202. Więcej: Daszkiewicz i in. 2010. 
ne przez W. Lubomirskiego i W. Polińskiego, skorupiaki peruwiańskie przez A. Wrześniowskiego, pajaki przez W. Taczanowskiego i T.T. Thorella ze Sztokholmu, motyle przez Ch. Oberthüra z Rennes i J. Prüffera, chrząszcze z rodziny Staphylinidae przez S. Solskiego z Petersburga, protoskrzydłe przez I. Bolivara z Madrytu, robaki przez A.E. Grubego z Wrocławia, ptaki przez: W. Taczanowskiego oraz J.L. Cabanisa z Muzeum Zoologicznego w Berlinie, P.L. Sclatera, O. Salvina i Godmana $z$ Londynu, K. Hellmayera z Monachium, H. Berlepscha z Kassel, R. Ridgwaya z Waszyngtonu, ryby, płazy i gady przez: A. Günthera z British Museum, F. Steindachnera z Imperial Museum w Wiedniu i A. Straucha z Petersburga, ssaki przez K. Petersa z Berlina i T. Oldfielda z British Museum, kolekcję czaszek peruwiańskich Jelskiego ${ }^{42}$ badał K. Stołyhwa. Na podstawie okazów Jelskiego opisano dziesiątki nowych gatunków. W Peru Jelski odkrył i złowił okaz ssaka Pakarana (Dinomys branickii), bardzo rzadkiego gryzonia opisanego następnie przez K. Petersa z Berlina.

W uznaniu jego zasług w kolekcjonowaniu fauny i flory Peru, Jelskiemu zadedykowano dziesiątki gatunków i podgatunków. Dla przykładu: ślimaki H. Crosse - Polystira jelskii, W. Lubomirski - Bulimus jelskii, W. Poliński - Nenia jelskiz; motyle Ch. Oberthür - Arctia jelskii, Heterusia jelskiaria, T. Pyrcz - Pedaliodes jelskii, J. Razowski i J. Wojtusiak - Netechma jelskii; chrząszcze S. Solski - Glenus jelskii, Philonthus jelskii, J. Wańkowicz - Lado jelskii; skorupiaki: E.J. Miers - Porcellio jelskii; mrówki C. Emery - Ažteca jelskii; pająki W. Taczanowski - Rhanis jelskii; ryby Steindachner F. - Tetragonopterus jelskii; płazy Peters W. Pseudobatrachus jelskii; ptaki J. Cabanis - Iridornis jelskii, Metallura jelskii, Upucerthia jelskii, J. Sztolcman - Empidonomus jelskii, Xenicopsoides montanus jelskii, W. Taczanowski - Thaluriana jelskii, Mustella jelskii, Picumnus jelskii, Ocbthoeca jelskii; rośliny I. Szyszyłowicz - Clavija jelskii, Gaultheria jelskii, Weinmania jelskii, C. Metz - Ajouea jelskii, Ocotea jelskii, A. Zahlbruckner - Amphilophium jelskii, Maytenus jelskii, G. Hieronymus - Diplostephium jelskii, Vernonia jelskii, Wedelia jelskii. J. Siemiradzki opisał górnojurajskiego amonita Perisphinctes jelskii, a W. Szajnocha scharakteryzował skamieniałego małża Pholadomyocardia jelskii z Peru dostarczonego mu przez Jelskiego ${ }^{43}$.

42 Znajdują się one dzisiaj w kolekcji Centrum Edukacji Przyrodniczej UJ.

43 Więcej: Tarkowski 2011; Flora perpetua... 2010. 
W pracach Raimondiego, jak choćby w El Peru (1874-1913), można znaleźć analizy chemiczne prób wody dostarczone z różnych części kraju właśnie przez Jelskiego. Korespondencja Jelskiego, Taczanowskiego i Sztolcmana z Raimondim przechowywana jest w Muzeum Raimondiego w Limie oraz w zbiorach Muzeum i Instytutu Zoologii PAN w Warszawie, w Archiwum Zgromadzenia Księży Misjonarzy w Krakowie. W Museo de Historia Natural „Javier Prado” w Limie wystawiane były okazy mineralogiczne i geologiczne z etykietkami noszącymi podpis Jelskiego ${ }^{44}$.

Jelski był dla Taczanowskiego głównym dostarczycielem okazów zwierząt, głównie ptaków oraz źródłem informacji na temat fauny południowoamerykańskiej. Odegrał znaczącą rolę w utworzeniu europejskich zoologicznych kolekcji neotropikalnych i przyczynił się znacząco do poznania przyrody tego kontynentu. Kolekcje okazów przesłanych przez Jelskiego z Gujany i Peru uczyniły zbiory Gabinetu Zoologicznego w Warszawie placówką na światowym poziomie.

Dzisiaj kolekcje faunistyczne, botaniczne i geologiczne Jelskiego rozproszone są w licznych, głównie w krajowych oraz europejskich kolekcjach instytucjonalnych. Bodaj najliczniejszy zbiór okazów zoologicznych przesłanych przez Jelskiego z Ameryki Południowej znajduje się w zbiorach Muzeum i Instytutu Zoologii PAN w Warszawie ${ }^{45}$. Gabinet Zoologiczny UJ wzbogacił się o dublety okazów Jelskiego z Gujany i Peru. W Instytucie Botaniki UJ w Krakowie znajduje się np. nieopracowany zbiór dendrologiczny oraz zielnik Jelskiego. Zbiór geologiczny Jelskiego, w tym okazy z Peru, znajdują się w Muzeum Instytutu Nauk Geologicznych PAN w Krakowie. Czaszki Indian peruwiańskich, zebrane przez Jelskiego, można oglądać w Muzeum Zoologicznym - Centrum Edukacji Przyrodniczej UJ ${ }^{46}$. W uznaniu zasług K. Jelskiego dla Peru, w 2015 r. w Limańskim Towarzystwie Geograficznym odsłonięto portret Konstantego Jelskiego ${ }^{47}$.

${ }^{44} \mathrm{Z}$ informacji Muzeum wynika, że brak jest niestety listy lub księi inwentarzowej pozwalającej na wyodrębnienie okazów zebranych przez Jelskiego. Więcej: Tarkowski, Daszkiewicz 2008.

${ }^{45}$ Część tych zbiorów uległa zniszczeniu w trakcie II wojny światowej. Z tych zachowanych, zebranych przez Jelskiego, na uwage zasługują w szczególności ptaki i pająki. Rewizja ptaków z Ameryki Południowej, zgromadzonych w zbiorach Muzeum i Instytutu Zoologii PAN, została przeprowadzona przez Mlikovski'ego 2009.

46 Tarkowski 2016, s. 98.

${ }^{47}$ Gołuchowska Dunin-Borkowska 2015, s. 517. 
Za namowa Adriana Baranieckiego (1828-1891) Jelski po powrocie do kraju napisał wspomnienia z Gujany Francuskiej i Peru ${ }^{48}$. Ten opis pracy przyrodnika w Ameryce Południowej był przeznaczony dla dziewcząt o poziomie wykształcenia równym maturze ${ }^{49}$.

\section{Jan Sztolcman (1854-1928)}

Podróżnik i eksplorator, wielki entuzjasta ornitologii Jan Sztolcman (1854-1928) był jednym z najbardziej znanych polskich podróżników i przyrodników końca XIX oraz początku XX wieku. Położył duże zasługi w eksploracji i zebraniu kolekcji zoologicznych w Peru oraz Ekwadorze $^{50}$.

W $\underline{1872}$ r. rozpoczą studia zoologiczne na Uniwersytecie Warszawskim. Tu zetknął się z W. Taczanowskim, kustoszem Gabinetu Zoologicznego przy Uniwersytecie, poznał Konstantego i Aleksandra Branickich. Szybko stał się pomocnikiem Taczanowskiego, specjalizując się pod jego kierunkiem w ornitologii, która stała się głównym polem pracy naukowej w ciagu całego jego życia. W 1875 roku przerwał studia uniwersyteckie i wyjechał w pierwszą 6-letnią podróż do Peru, sponsorowana przez hr. Aleksandra i Konstantego Branickich ${ }^{51}$, gdzie prowadził prace terenowe wspólnie z K. Jelskim. Obydwaj podróżnicy, połączeni węzłem jednakowych dążeń i jednego celu - służenia nauce, wspólnie przedsięwzięli poszukiwania, gromadząc zbiory, wzbogacając limańskie muzea i ogrody botaniczne, jak i europejskie. Podczas gdy Jelski kontynuowal rozpoczęte w 1873 roku prace (zbieranie okazów fauny, flory, prace geologiczne) dla Raimondiego, Sztolcman zbierał

\section{${ }^{48}$ Jelski 1898.}

49 W 2007 roku doczekały się francuskojęzycznego tłumaczenia P. Daszkiewicza., J.-Ch. de Masary i R. Tarkowskiego: Konstanty Jelski. Les histoires naturalistes populaires d'un séjour en Guyane française et en partie au Pérou (1865-1871). Choix.

${ }^{50}$ Więcej: Brzęk 2007; Domaniewski 1929; Jaczewski 1928; W. Słabczyński, T. Słabczyński 1992; Tarkowski 2011; Tarkowski i in. 2016.

${ }^{51}$ W 1873 roku K. Jelski, przebywający w Peru i pracujący wcześniej dla warszawskiego Gabinetu Zoologicznego, przyjął rządową posadę w charakterze eksploratora i zbieracza materiałów przyrodniczych, dla tworzonego wówczas w Limie muzeum pod kierownictwem A. Raimondiego. Wówczas to hr. K. Branicki i W. Taczanowski zaproponowali wyjazd do Peru J. Sztolcmanowi, który tę propozycję przyjął. Więcej: Tarkowski 2011; Tarkowski i in. 2016. 


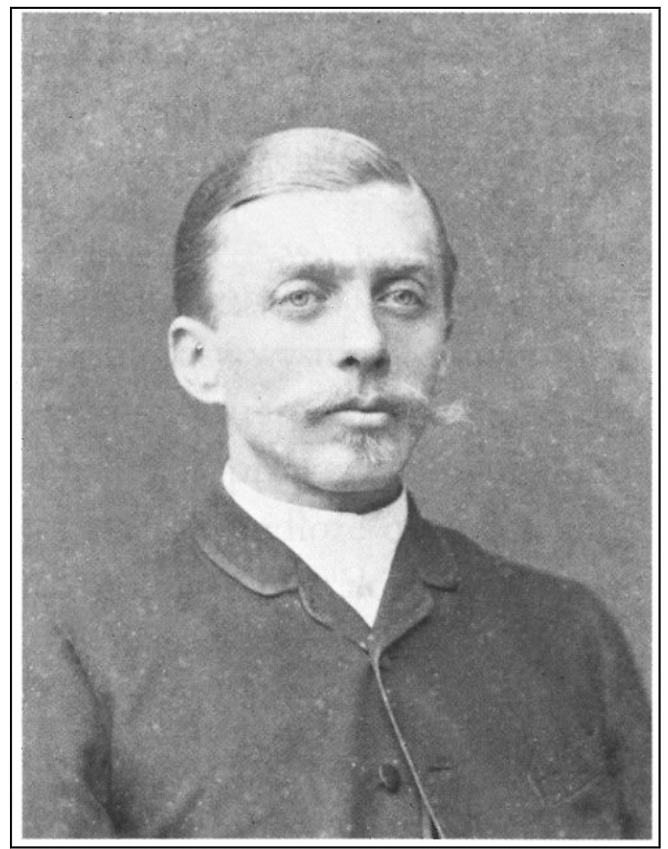

Ryc. 4. Jan Sztolcman (C) Muzeum i Instytut Zoologii PAN w Warszawie)

faunę neotropikalną dla Gabinetu Zoologicznego w Warszawie. Wspólnie z Jelskim badali okolice Limy i Andy na wschód od stolicy, północne wybrzeże Peru (Chimbote) aż po granicę z Ekwadorem oraz ujście rzeki Tumbez. Wobec decyzji powrotu Jelskiego do Europy, od połowy 1879 do 1881 roku Sztolcman prowadził dalsze badania samodzielnie, docierając aż do górnego dorzecza Amazonki, eksplorując dolinę Marañón i Huallaga w Kordylierze Centralnej. Droga przez Amazonkę i port brazylijski Belem powrócił w połowie 1881 roku do Europy.

W rok po powrocie do kraju, w 1882 wyruszył ponownie w druga już podróż do Ameryki Południowej, tym razem do Peru i Ekwadoru. Odbył ja w towarzystwie geologa i paleontologa, profesorem Uniwersytetu Lwowskiego - Józefa Siemiradzkiego ${ }^{52}$. Celem podróży było rozszerzenie terenu poprzednich badań ku północy i uzupełnienie poczynionych w Peru spostrzeżeń. Na skutek toczącej się wojny pomiędzy Peru i Chile, polscy przyrodnicy musieli udać się do sąsiedniego

52 Więcej: Wójcik 2000; Tarkowski i in. 2016. 
Ekwadoru, gdzie Sztolcman zbierał faunę na zachodnim stoku Kordylierów. Powrócił stamtąd do Warszawy w 1884 roku przywożąc bogate zbiory, głównie ornitologiczne. W $\underline{1887}$ r. objął stanowisko kustosza Muzeum Zoologicznego Branickich, przekształconego później w Państwowe Muzeum Zoologiczne ${ }^{53}$. W 1919 roku, z chwila powstania Państwowego Muzeum Zoologicznego, został mianowany wicedyrektorem; stanowisko to piastował aż do śmierci ${ }^{54}$.

Sztolcman jest autorem dwutomowej książki Peru - Wspomnienia z.podróśy z mapa $a^{55}$, liczącej 570 stron, będącej niezwykle dokładnym i wnikliwym opisem społeczeństwa, zwyczajów, polityki, a nade wszystko przyrody Peru końca XIX wieku. Zawiera ona olbrzymią ilość szczegółów istotnych dla współczesnych biologów, socjologów i historyków oraz informacje na temat relacji Polaków mieszkających w Peru. Stanowi ona ważny wkład Polski w poznanie tego kraju ${ }^{56}$.

Zbiory przyrodnicze przywiezione przez Sztolcmana dla warszawskiego Gabinetu Zoologicznego, głównie ornitologiczne, były równie bogate jak Jelskiego, zawierały liczne, nieznane dla nauki gatunki. Podobnie jak te Jelskiego, posłużyły Taczanowskiemu do opracowania monografii Ornithologie du Pérou (1884-1886). Część zatytułowana Généralités, na sześćdziesięciu stronach prezentuje opis Peru ${ }^{57}$. Wprowadzenie to jest uważane przez autorów peruwiańskich za jeden $z$ najlepszych opisów przyrodniczych tego kraju ${ }^{58}$.

${ }^{53}$ W roku 1901, razem z Józefem Potockim, Sztolcman odbył jeszcze jedną wyprawę badawczą do Sudanu w dorzecze Białego Nilu.

${ }^{54}$ Jan Sztolcman był zasłużonym działaczem łowiectwa polskiego. Był również aktywnym działaczem ochrony przyrody, inicjatorem programu ochrony żubra, członkiem Komisji Fizjograficznej i Komisji Geograficznej AU członkiem honorowym Towarzystwa Muzeum Tatrzańskiego, członkiem korespondentem Towarzystwa Przyrodników i Geografów w Moskwie, członkiem korespondentem Zoological Society of London. W Szkole Głównej Gospodarstwa Wiejskiego w Warszawie na Wydziale Leśnym wykładał łowiectwo. Więcej: Domaniewski 1929; Tarkowski $\mathrm{i}$ in. 2016.

55 Sztolcman 1912.

56 Podczas swoich podróży, oprócz opisywania rozmaitych gatunków zwierząt i roślin, wiele uwagi Sztolcman poświęcał na charakterystykę zwyczajów ludności indiańskiej. Zob. też: Tarkowski i in. 2016.

${ }^{57}$ Wyróżnionych „petitem”.

${ }^{58}$ Jako pracownik naukowy Sztolcman miał opinię badacza o niezwykłej wnikliwości, darze obserwacyjnym i inteligencji podróżnika. Był systematykiem, a większość 
Sztolcman jest również autorem kilkudziesięciu artykułów naukowych zarówno samodzielnych, jak i współautorskich, np. z hr. Hansem Berlepschem, przeszło 300 publikacji popularnonaukowych, książek oraz innych opracowań. Opisał przeszło 150 nowych dla nauki gatunków i podgatunków ptaków, część z nich nazwał na cześć polskich zoologów ${ }^{59}$. Niezwykle silnie rozwinięty dar obserwacyjny pozwolił mu zebrać olbrzymie materiały z zakresu obyczajów zwierząt. Opublikował kilkadziesiąt popularnych artykułów o przyrodzie Ameryki Południowej.

Na materiałach Sztolcmana pracowali liczni przyrodnicy: H. Berlepsch, J.L. Cabanis, A. Günther, Ch. Obertthür, K. Peters, P.L. Sclater, F. Steindachner, R. Ridgway, O. Thomas, A. Thorell oraz H. Dzieduszycki, W. Lubomirski, S. Solski, W. Poliński, J. Rostafiński, W. Taczanowski, A. Wrześniowski oraz inni. W ocenie zasług zadedykowano Sztolcmanowi szereg nowo opisanych gatunków zwierząat ${ }^{60}$, w tym ptaków, ssaków oraz motyli. np.: Taczanowski - Colaptes stolzmanni, Domaniewski - Catharus dryas sztolcmani, Sitta europaea sztolcmani, Taczanowski \& Berlepsch - Urothraupis stolzmanni, Mustela sz̧tolżmanni oraz liczne inne.

\section{Kalinowski Jan (1857-1941)}

Urodzony w 1857 roku na Mazowszu, podróżnik i zoolog Jan Kalinowski przybył do Peru w 1889 roku i pozostał w tym kraju aż do śmierci w 1941 roku $^{61}$.

Po ukończeniu szkoły elementarnej oddany został na służbę dworską do Branickich pod Warszawą, gdzie z biegiem lat wykształcił się na doskonałego strzelca i obserwatora przyrody. Lata 1879-1883 spędził na Kamczatce jako asystent przyrodnika Benedykta Dybowskiego $^{62}$, w latach 1883-1888 samodzielnie eksplorował Koreę i Japonię, zbierając okazy zoologiczne dla Muzeum Zoologicznego Branickich ${ }^{63}$.

jego prac jest poświęcona systematyce ptaków; zajmował się głównie fauną neotropikalną, której był wybitnym znawcą.

${ }^{59}$ Jak wspominają Piechnik, Kurek 2016, ss. 285-287, część z tej dużej liczby odkryć ornitologicznych współcześnie traktowana jest jako synonimy.

${ }^{60}$ Mierzwa-Szymkowiak, Breure 2017.

${ }^{61}$ Więcej: J.S. Kalinowski 2017; Piechnik, Kurek 2016.

${ }^{62}$ Kalinowski pełnił funkcję przybocznego strzelca i preparatora.

${ }^{63} \mathrm{~W}$ ciagu 5-letniej współpracy obaj badacze przemierzyli w celach przyrodniczych pięciokrotnie półwysep, eksplorując po drodze miejscową faunę. Po wyjeździe 


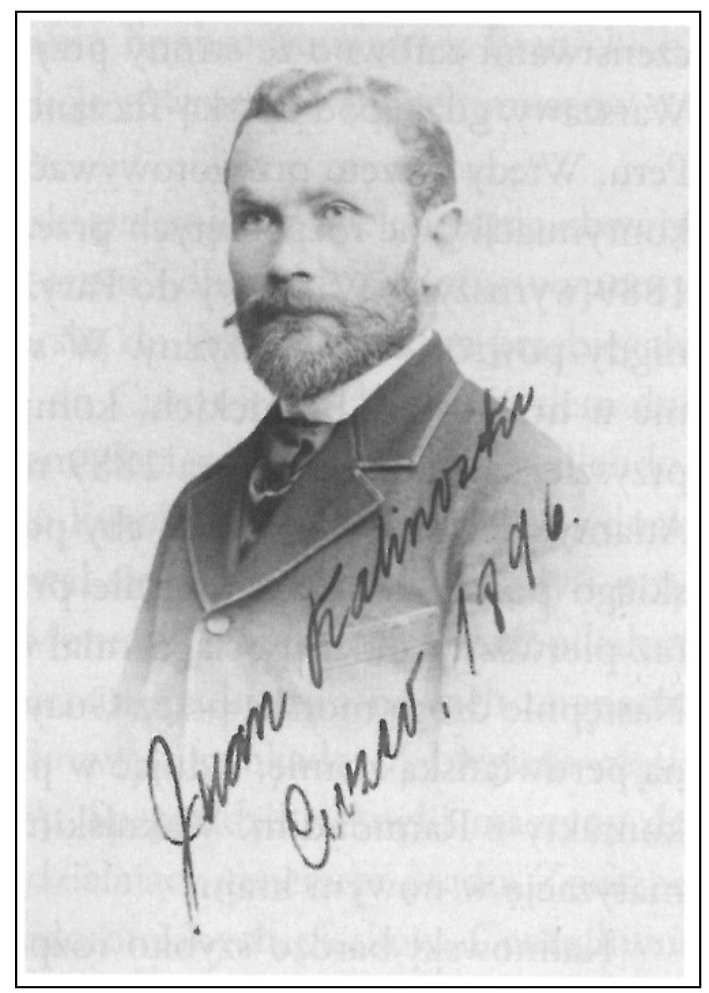

Ryc. 5. Jan Kalinowski (C Muzeum i Instytut Zoologii PAN w Warszawie; ze zbiorów Julio Sumar Kalinowski)

W 1889 roku Kalinowski został wysłany przez Ksawerego Branickiego (syna zmarłego w r. 1884 Konstantego) na eksplorację Peru i Boliwii, celem kontynuacji wcześniejszych, pomyślnych badań zapoczątkowanych przez Jelskiego i Sztolcmana. W połowie sierpnia 1889 roku dotarł na ziemię peruwiańską, gdzie w Limie nawiązał kontakt z A. Raimondim, X. Wakulskim i E. Malinowskim. W okresie od sierpnia 1889 do maja 1894 roku eksplorował centralne Peru, na obszarach częściowo pokrywających się z terenami działalności swoich poprzedników ${ }^{64}$. Gromadził i wysyłał zbiory do kierowanego przez Sztolcmana Muzeum

Dybowskiego w roku 1882 na katedrę zoologii do Lwowa, Kalinowski - finansowany przez Branickiego - pozostawał jeszcze przez 5 lat w Azji, eksplorując faunę okolic Władywostoku, kraju Usuryjskiego i Japonii.

${ }^{64}$ Okolice Limy, jeziora Junin, Tarmy, Chanchamayo, Maraynioc. 
Branickich, dublety ptaków i ssaków przesyłał również prof. B. Dybowskiemu do Lwowa ${ }^{65}$. W okresie od maja 1894 do lipca 1898 roku eksplorował południowe Peru, zwłaszcza departamenty Cusco i Puno. W 1896 roku odbył wyprawę do departamentu La Paz w północnej Boliwii, skąd przywiózł wiele okazów ptaków. Intensywną współpracę z ośrodkiem warszawskim prowadził do 1902 roku $^{66}$. Mając szerokie kontakty dostarczał kolekcje do innych muzeów na całym świecie ${ }^{67}$.

Około 1898 roku osiadł w wyżynnej krainie w południowo-wschodnim Peru, na farmie Cadena w dolinie Marcapata ${ }^{68}$. Zamieszkawszy na własnej farmie ożenił się z Marią Villamonte, hiszpańskiego pochodzenia Peruwianka, z którą doczekał się licznego potomstwa ${ }^{69}$. Był pionierem osadnictwa na tych terenach, hodował rośliny uprawne, m.in. trzcinę cukrową i awokado. Znaczne dochody uzyskiwał z płukania złotonośnych piasków ${ }^{70}$. Sprowadził z Anglii maszyny do tłoczenia trzciny cukrowej, posiadał nawet własny generator prądu.

Zmarł w czerwcu 1941 roku i pochowany został na farmie w Cadenie.

Długie lata spędzone przez Kalinowskiego w Ameryce Południowej zaowocowały odkryciem wielu nowych gatunków zwierząt, głównie ptaków. Zbiory Kalinowskiego były przedmiotem opracowań innych badaczy, którzy nazwiskiem polskiego faunisty nazwali szereg nowych gatunków i podgatunków ptaków, jak te opisane przez Berlepscha

${ }^{65}$ Utrzymywał kontakty z Benedyktem Dybowskim, o czym świadczy zachowana korespondencja w zbiorach Muzeum i Instytutu Zoologii PAN w Warszawie.

${ }^{66}$ Do momentu zaprzestania finansowania przez Branickich.

${ }^{67}$ Więcej: J.S. Kalinowski 2017; Piechnik, Kurek 2016, ss. 197-202.

${ }^{68} \mathrm{~W}$ połowie drogi z Cuzco do Puerto Maldonado.

${ }^{69}$ Kalinowski pozostawił najliczniejszą rodzinę pochodzenia polskiego w Peru. Chociaż żadne z dzieci nie władało językiem polskim, to jednak każde było dumne, że ojciec jest „origine Polaco”. Więcej: J.S. Kalinowski 2017; Los Polacos en el Perú 1979; Paradowska 1977.

${ }^{70}$ Kalinowski w liście z 10 stycznia 1906 z Cadeny do B. Dybowskiego wspomina, że: ,[...] zdecydowałem zająć się gospodarstwem i we wschodnim Peru w dolinie Marcapata założyłem fermę trzciny cukrowej, kawy koka i kakao, oraz inne owoce banany, ananasy i etc. [...] sprowadziłem maszyny ze Stanów Zjednoczonych, lecz nie są jeszcze urządzone, tem czasem na małą skalę pędzę gorzałkę i wyrabiam cukier. [...] Obecnie także zajmuję się zbiorami kolekcji, lecz mniej jak uprzednio z powodu tego, że mam dużo zajęcia fermą. [...] Dolina Marcapata jest nader obfita w ptaki i zwierzęta, oraz gutaperka i kopalnie złota, brakuje tylko kapitałów i rąk do pracy. Ja od czasu do czasu także myję złoto". 
\& Sztolcmana - Nothoprocta kalinowskii, Macropsalis kalinowskii, Dives kalinowskii ${ }^{71}$ czy przez Taczanowskiego - Thirponax kalinowskii. Kilka gatunków ssaków w nazwie łacińskiej nosi jego nazwisko, jak np. gryzoń aguti Dasyprocta kalinowskii czy kuropatwa Nothoprocta kalinowskii.

Oprócz awifauny, gromadził także okazy teriofauny peruwiańskiej, wzbogacając kolekcje kilku światowych muzeów przyrodniczych (m.in. w Warszawie, Londynie, Waszyngtonie, Lwowie, Limie). W odróżnieniu od swoich poprzedników nie stronił od pozyskiwania i preparowania dużych gatunków ssaków (np. wikunia północna, pekariowiec obrożny, mulak białoogonowy $)^{72}$. Zdobyte przez siebie okazy ssaków etykietował według zaleceń, jakie przed laty wprowadził Taczanowski, tj. często umieszczając nawet dłuższe opisy na temat środowiska, w którym dany gatunek został pozyskany, a także informacje o jego zachowaniu w naturze. W skład licznego zbioru teriologicznego, zgromadzonego przez Kalinowskiego w Peru, wchodziło wiele okazów z miejsc dotychczas niezbadanych. Na podstawie zebranych przez niego okazów opisano kilkanaście nowych dla nauki gatunków ssaków, do których należą wśród nietoperzy - goblinek Kalinowskiegio Mormopterus kalinowskii Thomas, a wśród gryzoni wiewiórka andowiak Kalinowskiego Thomasomys kalinowskii Thomas, krabojadek Sztolcmana Ichthyomys stolzmanni Thomas, aguti Kalinowskiego Dasyprocta kalinowskii Thomas $^{73}$.

Kalinowski utrzymywał kontakt z krajem. W związku z innymi zajęciami i brakiem czasu na zbieranie okazów, proponował wyszkolenie u siebie przysłanego z Polski zbieracza ${ }^{74}$. Pozostawał w kontakcie listownym z Benedyktem Dybowskim. Po I wojnie światowej próbował nawiązać kontakty z Państwowym Muzeum Ziemi, korespondując ze Sztolcmanem, a potem J. Domaniewskim ${ }^{75}$. Wysyłał zbiory dla Muzeum Przyrodniczego Branickich, jak również do Anglii i Stanów Zjednoczonych. Oprócz listów, z wypraw Kalinowski nie pozostawił po sobie

71 Więcej: Berlepsch, Stolzmann 1892; 1896; 1906.

72 Piechnik, Kurek 2016, s. 202.

${ }^{73}$ Jak podkreśla Piechnik, Kurek 2016 bardzo ważny dorobek Kalinowskiego w dziedzinie teriologii jest niestety słabo znany.

${ }^{74}$ Ze względów finansowych przyjazd tego zbieracza nie doszedł on do skutku.

${ }^{75}$ Świadczą o tym listy J. Kalinowskiego do J. Sztolcmana i J. Domaniewskiego przechowywane w Muzeum i Instytucie Zoologii PAN w Warszawie. 
żadnych publikacji. Na początku XX wieku sporadycznie zasilał bezinteresownie muzea przyrodnicze w Warszawie. Okazy przesłane przez Kalinowskiego można obecnie znaleźć w licznych kolekcjach przyrodniczych w Europie i Ameryce. Nazwisko jego stało się znane w kołach muzealników całego świata. Jego pracownię preparatorską odwiedził nawet prezydent Peru, podziwiając zgromadzone zbiory ${ }^{76}$.

\section{Podsumowanie}

Konstanty Jelski, Jan Sztolcman oraz Jan Kalinowski dostarczyli setki okazów fauny i flory neotropikalnej zebrane w Ameryce Południowej w Peru do zbiorów instytucjonalnych w Europie, Ameryce Północnej i Południowej. Były to nie tylko okazy, ale i szczegółowe opisy zawierające informacje o jej występowaniu, środowisku życia, zróżnicowaniu morfologicznym oraz inne.

$\mathrm{Na}$ podstawie tych materiałów wielu europejskich przyrodników opisało dziesiątki gatunków zwierząt i roślin nieznanych dotychczas dla nauki. Chociaż część z nich weszła do synonimiki, liczba nowych gatunków jest imponująca. W uznaniu zasług polskim przyrodnikom i odkrywcom zadedykowano dziesiątki nowych gatunków zwierząt i roślin.

Dostarczone okazy ptaków dla W. Taczanowskiego stanowiły materiał do napisania Ornithologie du Pérou, pierwszej i najobszerniejszej w XIX wieku monografii fauny neotropikalnej. Ze względu na bogactwo okazów uczyniły z warszawskiego Gabinetu Zoologicznego ośrodek badań fauny neotropikalnej, głównie ptaków, na światowym poziomie.

Okazy i informacje pozyskane przez polskich przyrodników w Peru stanowily dla A. Raimondiego znacząca pomoc w opracowaniu wielotomowego dzieła El Peru.

${ }^{76}$ Synowie J. Kalinowskiego, Celestyn i Benedykt, interesowali się kolekcjonowaniem zbiorów przyrodniczych. Pod koniec lat pięćdziesiątych XX w. C. Kalinowski zdołał przekonać rząd Republiki Peru do utworzenia Parku Narodowego Manu, jednego z najważniejszych chronionych obszarów naturalnych w tropikach na całym świecie. Więcej: J.S. Kalinowski 2017. 


\section{Bibliografia}

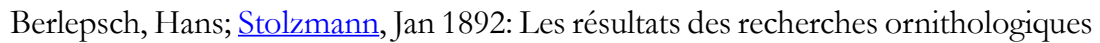
faites au Pérou par M. Jean Kalinowski. Proceedings of the Zoological Society of London, ss. 371-410.

Berlepsch, Hans; Stolzmann, Jan 1896: On the ornithological researches of M. Jean Kalinowski in Central Peru. Proceedings of the Zoological Society of London, ss. 322-388.

Berlepsch, Hans; Sztolcman, Jan 1906: Rapport sur les nouvelles collections ornithologiques faites au Pérou par M. Jean Kalinowski. Ornis 13, pp. 63-133.

Bratkowski, Stefan 1975: Inżynierowie Babińscy. Kwartalnik Historii Nauki i Techniki 2, ss. 295-311.

Broggi, Jorge 1926: Raimondi Géologo. Boletin Sociedad Geografica de Lima 43, ss. $460-468$.

Brzęk, Gabriel 2007: Historia zoologii w Polsce do drugiej wojny światowej. Aktualizacja i uzupetnienia: J. Pawtowski i T. Majewski. „Rozprawy Wydziału Przyrodniczego PAU”, t. 2, Kraków: Polska Akademia Umiejętności.

Daszkiewicz, Piotr 1997: W cieniu Maison Verreaux: Paryżpolskich prayrodników kolekcjonerów. Warszawa: Neriton.

Daszkiewicz, Piotr 2005: Quelques remarques sur l'Ornithologie du Pérou la première monographie de la zoologie néotropicale. Organon 34, pp. 73-96.

Daszkiewicz, Piotr; Tarkowski, Radosław 2007a: Nowe dane dotyczące związków Antonio Raimondiego (1824-1890) z polskimi uczonymi i inżynierami oraz udziału Polaków w geologicznym opisie Peru. Czasopismo Geograficzne 1-2, ss. $121-130$.

Daszkiewicz, Piotr; Tarkowski, Radosław 2007b: Listy Edwarda Habicha (18351909) do Ignacego Domeyki (1802-1899) ze zbiorów Biblioteki Polskiej w Paryżu. Kwartalnik Historii Nanki i Techniki 52/2, ss. 203-212.

Daszkiewicz, Piotr; Tarkowski, Radosław 2007c: Antonio Raimondi (1824-1890) w korespondencji polskich przyrodników Konstantego Jelskiego, Władysława Taczanowskiego i Jana Sztolcmana. Polskie badania środowiska przyrodniczokulturowego w Ameryce Lacińskiej. Kraków 28-30 maj 2007. [W:] „Materiały ogólnopolskiej konferencji naukowej”. Instytut Botaniki im. W. Szafera PAN, ss. $69-70$.

Daszkiewicz, Piotr; Tarkowski, Radosław; De Massary, Jean Christophe 2010: Konstanty Jelski (1837-1896) i jego działalność w zakresie nauk przyrodniczych. Dokumenty z Archiwum K. Jelskiego - unikalne materiały dla historii nauk przyrodniczych Francuskiej Gujany. Prace Komisji Historii Nauki PAU X, 
ss. 225-240. Dostęp online: http://pau.krakow.pl/PKHN-PAU/pkhn-pauX-2010-13.pdf.

Daszkiewicz, Piotr; Tarkowski, Radosław 2020: Studia we Francji oraz pierwsza praca Ignacego Domeyki (1802-1889). Przeglad Geologiczny 68(1), ss. 16-20.

Dembicz, Andrzej; Smolana, Krzysztof 1993: La presencia polaca en América Latina. CECLA Warszawa.

Deustua, José 1986: La minería peruana y la iniciación de la república, 1820-1840. Lima: IEP, Instituto de estudios peruanos.

Domaniewski, Janusz 1929: Jan Sztolcman 1854-1928. Prace Państwowego Muzeum Zoologicznego. Wiadomości z Muzeum, ss. 23-48.

Flora perpetua. Arte y ciencia botánica de Antonio Raimondi 2010. Luis Felipe Villacorta Ostolaza Editor cientifico. Tom I-III. Lima: Asociacion Educacional Antonio Raimondi - Centro di Lingua e Cultura Italiana - Museo Raimondi.

Gołuchowska Dunin-Borkowska, Katarzyna 2015: Peruwiańczycy odkrywaja zasługi Konstantego Jelskiego (1837-1896) dla przyrodniczego poznania Peru. Przeglad Geologiczny 63 (9), ss. 516-518.

Jaczewski, Tadeusz 1928: Jan Sztolcman. Wspomnienie pośmiertne. Morze. Organ Ligi Rzuecrnej i Morskiej 6, ss. 22-23.

Jelski, Konstanty 1898: Popularno-prayrodnicze opowiadania z pobytu w Gujanie francuskiej i po cześsi w Peru (od roku 1865-1871). Kraków: W drukarni „Czasu” Fr. Kluczyckiego i Spółki.

Jelski, Konstanty 2007 : Les histoires naturalistes populaires d'un séjour en Guyane française et en partie au Pérou (1865-1871). Choix, Traduction et élaboration scientifique par P. Daszkiewicz, J.-Ch. de Massary, R. Tarkowski. Wydawnictwo Naukowe Akademii Pedagogicznej, Kraków.

Kalinowski, Julio Sumar 2017: De la tundra a la jungla. Jan Kalinowski. Una Historia Natural. Lima.

Kochanek, Padre Kazimierz (red.) 1979: Los Polacos en el Peru. Libro auspiciado por la Embajada de la Republica Popular de Polonia en el Perú. Lima: Editorial Salesiana Lima.

Lopez Soria, José I. 1986: Polak zperuwiańskiego pomnika Edward Habich. Przedmowa i komentarze Stefan Bratkowski i Bolesław Orłowski. Warszawa: Państwowe Wydawnictwo „Iskry”.

Lopez Soria, José I. 1999a: Historia de la Universitad Nacional de Ingenieria. Lima: UNI-Lima.

Lopez Soria, José I. 1999b: Eduardo J. De Habich. Lima: UNI-Lima. 
Mierzwa-Szymkowiak, Dominika; Breure, Bram 2017: Inside and outside Neotropics: Three Polish naturalists during the late $19^{\text {th }}$ and early $20^{\text {th }}$ century. Archives of Natural History 44(1), pp. 151-158.

Mlíkovský, Jiří 2009: Types of birds in the collections of the Museum and Institute of Zoology, Polish Academy of Sciences, Warszawa, Poland. Part 3: South American birds. Journal of the National Museum (Prague), Natural History Series 178 (5), pp. 17-180.

Museo Raimondi Asociación Educacional Antonio Raimondi 2020: Antonio Raimondi. Biografía. Dostęp online (10.08.2020): http://museoraimondi.org. pe/es/contenido/12/bibliografía.

Muzeum i Instytut Zoologii Polskiej Akademii Nauk 2020: Historia Muzeum i Instytutu Zoologii - całość. Dostęp online (10.08.2020): https://www.miiz. waw.pl/pl/podstawowe/574-historiamiiz.

Orłowski, Bolesław (red.) 1984: Stownik polskich pionierów techniki. Wydawnictwo Śląsk, Katowice 1984.

Orłowski, Bolesław 1992: Osiagnięcia inṡynierskie Wielkiej Emigracji. Instytut Historii Nauki, Oświaty i Techniki PAN, Warszawa.

Paradowska, Maria 1977: Polacy w Ameryce Południowej. Ossolineum, Wrocław Warszawa-Kraków-Wrocław.

Paradowska, Maria 1984: Podróżnicy i emigranci: sqkice z dziejów polskiego wychodśstwa $w$ Ameryce Poludniowej. Interpress. Warszawa.

Paulo, Andrzej 2010: History of Polish geological studies in Latin America. The Nature and Culture of Latin America. Review of Polish Studies (Z. Mirek, A. Flakus, A. Krzanowski, A. Paulo, J. Wojtusiak, eds.). Szafer Institute of Botany, Polish Academy of Sciences, Kraków, pp. 13-46.

Peru 2002: [W:] Encyklopedia Britannica - edycja polska. 2002, T. 31. Wydawnictwo Kurpisz. Poznań, ss. 408-411.

Piechnik, Łukasz; Kurek, Przemysław 2016: Ssaki neotropików odkryte przezpolskich naturalistów. Instytut Botaniki im. W. Szafera PAN, Kraków.

Raimondi, Antonio 1874-1913: El Peru. Imprenta del Estado et La sociedad geográfica de Lima, t. I-V, Lima.

Rudowska, Maria 1975: Polscy inşynierowie w Peru w drugiej połowie XIX w. Problemy Polonii Zagranicznej 9, ss. 145-188.

Ryn, Zdzisław J. (red.) 2002: Ignacy Domeyko: obywatel swiata. Wydawnictwo Uniwersytetu Jagiellońskiego, Kraków.

Seiner Lizarraga, Lizardo 2003: Antonio Raimondiy sus vinculaciones con ciencia europea, 1851-1890. Bulletin de l'Institut Français d'Etudes Andines 32 (3), pp. 517-537. 
Słabczyński, Wacław; Słabczyński, Tadeusz 1992: Stownik Podróżników Polskich. Wiedza Powszechna Warszawa.

Sztolcman, Jan 1912: Peru. Wspomnienia z Podróży z. mapa. Vol. 1-2. Gebethner i Wolf, Warszawa.

Taczanowski, Władysław 1884-1886: Ornithologie du Pérou. t.1: 1884; t. 2:1884; t. 3: 1866; t. 4: 1886. Typographie Oberthur Rennes.

Taczanowski, Władysław 1964: Listy do Antoniego Wagi, Konstantego Branickiego i Benedykta Dybowskiego. W opracowaniu K. Kowalskiej, A. Mroczkowskiej i B. Zielińskiej. Memorabilia Zoologica 12, ss. 1-317.

Tarkowski, Radosław 2011: Konstanty Jelski (1837-1896). Prayrodnik i badacz. Ameryki Południowej. Wydawnictwo Uniwersytetu Pedagogicznego w Krakowie. „Prace Monograficzne" nr 605, Kraków.

Tarkowski, Radosław 2012: Życie i działalność Konstantego Jelskiego - prayrodnika i badacza Ameryki Południowej. Prace Komisji Historii Nauki PAU Kraków XI, ss. 325-339.

Tarkowski, Radosław 2016: Współpraca Antonio Raimondiego (1824-1890) z polskimi przyrodnikami i inżynierami w Peru. Przeglad Geologiczny 2, ss. 93-100.

Tarkowski, Radosław; Daszkiewicz, Piotr 2008: Działalność Konstantego Jelskiego (1837-1896) w zakresie geologii. Przeglad Geologiczny 5, ss. 373-377.

Tarkowski, Radosław; Goluchowska, Katarzyna 2013: Konstantyn Jelski (1837-1896) naturalista e investigador de America Latina. Lima: Sociedad Geographica de Lima.

Tarkowski, Radosław; Goluchowska Trampczynska, Katarzyna 2016: Memorias de Jan Sztolcman y su contribución al conocimiento del noreste de Cajamarca (1877-1879). [In:] XI Congreso Nacional de Geografía a realizarse en la ciudad de Cajamarca del 5 al 7 de octobre de 2015. Memoria del XI Congreo Nacional de Geogarfía 2015, Sociedad Geografica de Lima, pp. 423-438; ISBN: 978-612-4344-03-9.

Tarkowski, Radosław; Pyrcz, Tomasz; Goluchowska Dunin-Borkowski, Katarzyna 2017: Memorias del naturalista polaco Jan Sztolcman de su viaje al Perú entre 1875-1881. Lima: Sociedad Geografica de Lima.

Villacorta, Luis F. 2010: Antonio Raimondi. La naturaleza y la Nación. [In:] L.F. Villacorta Ostolaza (ed.), Flora perpetua. Arte y ciencia botánica de Antonio Raimondi. Lima, t. III, pp. 64-101.

Vuilleumier, François 2003: Perspectives in Ornithology Neotropical Ornithology. Then and Now. The Auk. 120 (3), pp. 577-590.

Warszewicz Józef 1987: Krystyna Guntherowa. [W:] S. Feliksiak (red.), Stownik biologów polskich. Warszawa: PWN, ss. 565-566. 
Warszewicz Józef. A. Zemanek [W:] Polski wkład w Przyrodoznawstwo i Technikę. [W:] Stownik Polskich $i$ zwiazanych z Polska odkrywcón oraz Pionierów nauk matematyczno-prayrodniczych i Techniki, 2015, T. IV, ss. 353-355.

Wąsowska, Monika; Winiszewska-Ślipińska, Grażyna 1996: The history of the Collection of Neotropical Fauna in the Museum and Institute of Zoology PAS. Unit 1939. Bulletin of the Museum and Institute of Zoology PAS (Supplement to Annales Zoologici) 1, pp. 29-34.

Wielopolska, Salomea, M. 1974: Wstep i postowie do F. Woytkowski Peru moja ziiemia nie obiecana. Ossolineum.

Woytkowski Feliks. Krystyna Kowalska. [W:] S. Feliksiak (red.), Słownik biologów polskich. Warszawa: PWN, ss. 589-590.

Wójcik, Zbigniew 2000: Józef Siemiradzki. Pryyrodnik i bumanista, badacz. Ameryki Poludniowej. Wrocław -Warszawa: Stowarzyszenie "Wspólnota Polska".

Wulf, Andrea 2017: Czlowiek, który zrozumiat nature. Nowy swiat Alexandra von Humboldta. Tłumaczenie K. Bażyńska-Chojnacka i Piotr Chojnacki. Poznań: Wydawnictwo Poznańskie sp. z o.o.

\section{Spis ilustracji}

Ryc. 1. Władysław Taczanowski (Muzeum i Instytut Zoologii PAN w Warszawie).

Ryc. 2. Pomnik A. Raimondiego w Limie w dzielnicy Barranco na placu jego imienia (zdjęcie własne autora).

Ryc. 3. Portret K. Jelskiego z pracy pt.: Popularno-prayrodnicze opowiadania z pobytu w Gujanie Francuskiej i po cześci w Peru (od roku 1865-1871). Zdjęcie pochodzi z ok. 1875 roku.

Ryc. 4. Jan Sztolcman (Muzeum i Instytut Zoologii PAN w Warszawie).

Ryc. 5. Jan Kalinowski (Muzeum i Instytut Zoologii PAN w Warszawie; ze zbiorów Julio Sumar Kalinowski).

\section{List of illustrations}

Fig. 1. Władysław Taczanowski (Museum and Institute of Zoology of the Polish Academy of Sciences in Warsaw).

Fig. 2. Monument A. Raimondi in Lima in the Barranco district in the square named after him (Author's own photo). 
Fig. 3. Portrait of K. Jelski from the work entitled: Popularno-prayrodnicze opowiadania z pobytu w Gujanie Francuskiej i po cześci w Peru (od roku 1865-1871). The photo is from around 1875 .

Fig. 4. Jan Sztolcman (Museum and Institute of Zoology of the Polish Academy of Sciences in Warsaw).

Fig. 5. Jan Kalinowski (Museum and Institute of Zoology of the Polish Academy of Sciences in Warsaw; from the collection of Julio Sumar Kalinowski). 